\title{
Spontano generirani pokreti kao prediktori neurorazvojnih poremećaja
}

\author{
Ivana Jandroković, Jasmina Stošić \\ Edukacijsko-rehabilitacijski fakultet Sveučilišta u Zagrebu, Zagreb, Hrvatska
}

\begin{abstract}
Sažetak: $U$ ovom radu prikazane su dosadašnje spoznaje o spontano generiranim pokretima (SGP) te njihova moguća ulogu prediktora neurorazvojnih poremećaja. Prema najnovijim podacima, jedno od šestero djece tijekom rane dobi razvije neki od neurorazvojih poremećaja. Metode i tehnike predviđanja i probira rizične djece za mogućnost razvoja nekog od neurorazvojnih poremećaja dosta su ograničene. Spontano generirani pokreti (SGP) u neonatalnom periodu indikator su spontane neuralne aktivnosti, te time i dobar pokazatelj oštećenja mozga. Danas je dobro poznato kako je procjena SGP-a visoko prediktivna za razvoj cerebralne paralize, no manje je poznata njena vrijednost kao prediktora za druge poremećaje koji nisu motorički. Mnoga istraživanja pokazala su da su atipični SGP indikator oštećenja mozga ili disfunkcije subplate zone, što posljedično može voditi disfunkciji u mnogim vještinama koje su posljedica optimalnog funkcioniranja kompleksnih kortiko-subkortikalnih neuralnih krugova. Na taj način procjena spontano generiranih pokreta može biti prediktivna za neurorazvojne poremećaje te omogućiti pravovremeno uključivanje u programe rane stimulacije i rane intervencije.
\end{abstract}

Ključne riječi: spontano generirani pokreti, procjena spontano generiranih pokreta, neurorazvojni poremećaj, poremećaj iz spektra autizma

\section{UVOD}

Iako se ranije smatralo kako su razvojni procesi na različitim područjima zapravo paralelni procesi koji se odvijaju nezavisno jedan od drugog, danas se zna da su oni međusobno isprepleteni (Diamond, 2000), no ne nužno i kako.

Razvoj grube motorike prvi je od jasnih vidljivih elemenata adaptivnog ponašanja kod novorođenčeta. S obzirom na činjenicu kako motoričko učenje zahtijeva više povezanih kognitivnih operacija, uključujući percepciju i motoričko planiranje, poznavanje neurobiologije razvoja motoričkih funkcija može nam pružiti uvid u mehanizme kognitivnog razvoja (Hofsten, 2004). U literaturi je već dobro zabilježeno kako motoričke i kognitivne vještine sazrijevaju kroz iste trajektorije. Mobilnost je ključna za kognitivno funkcioniranje, pomažući u formiranju neuronskih veza i diferencijacije moždane kore kroz pokret $\mathrm{i}$ istraživanje 
okoline koje dovodi do toga da malo dijete stječe iskustva, uči i uočava uzročno-posljedične veze u okolini. Ipak, sve navedeno jedino utvrđuje međuodnos motoričkog i kognitivnog razvoja kao isključivo bihevioralne posljedice koja nam omogućuje kretanje, znači motoričke vještine. No postavlja se pitanje je li međuodnos motoričkog i kognitivnog funkcioniranja više od bihevioralne posljedice? Jesu li zapravo isti neuralni i neurofiziološki mehanizmi ti koji stvaraju međuodnos motorike i kognicije? Možemo li ih mjeriti i opažati, te u slučaju deficita intervenirati na njih? Jedna od prvih motoričkih funkcija koja se pojavljuje nakon rođenja, a koja je do danas značajno zanemarena u sustavu praćenja razvoja novorođenčadi su tzv. spontano generirani pokreti (SGP).

Cilj ovog rada je prikazati dosadašnje spoznaje o spontano generiranim pokretima te njihovu moguću ulogu prediktora neurorazvojnih poremećaja.

\section{Neurobiološka osnova razvojnih vještina}

Od prvog dana djetetova rođenja pažnja roditelja i stručnjaka usmjerena je na praćenje razvoja, iščekivanje novih vještina i usvajanje razvojnih miljokaza kod novorođenčeta. To praćenje naročito je sustavno tijekom prve godine djetetova života. U slučaju patologije i manjeg dijela jednog od tih sustava posljedice se odražavaju i u ostalim sustavima djetetova funkcioniranja (Marrus i sur., 2018). Ipak, od svih područja razvoja onaj naočitiji pokazatelj napretka u najranijoj dobi, a i onaj kojemu se pridaje najviše pažnje tijekom prve godine života djeteta je motorički razvoj. Prvi razlog tomu je što su motorički razvojni miljokazi očiti i dobro prepoznatljivi, a drugi jer je to dio razvoja za koji se smatra da je najprimarni- ji i najbrži u sazrijevanju. Prohodavanje malog djeteta signalizira novorođenačko sazrijevanje u obliku osamostaljivanja i širenja mogućnosti za istraživanje okoline, učenje i socijalnu interakciju (Marrus i sur., 2018). Iako su grube motoričke funkcije i motorički razvojni miljokazi kod novorođenčeta i hodančadi jasno i dobro istraženi, mjerljivi kroz niz razvojnih ljestvica te naširoko korišteni u kliničkom radu i praćenju malog djeteta, studije o neuralnim mehanizmima koji dovode do razvoja vještina grube motorike još su uvijek ograničene. Različite regije mozga podupiru motoričko funkcioniranje. Neke od njih su i mali mozak i prefrontalni korteks (Niendam i sur., 2012). To su dijelovi mozga koji su ujedno uključeni u kognitivnu kontrolu (Diamond, 2000). Dok dojenčad komunicira s vanjskim okruženjem, mozak reagira na taj unos (Leisman i Melillo, 2013). Tako je snimanje mozga preko magnetne rezonance otkrilo da povećana tjelesna aktivnost potiče stvaranje sive tvari u mozgu (Halloway, Arfanakis, Wilbur, Schoeny i Pressler, 2018). Nadalje, istraživanja su pokazala da je rani motorički razvoj povezan s kasnijim kognitivnim ishodom, uključujući akademska postignuća i izvršno funkcioniranje (Murray i sur., 2006; Bornstein, Hahn i Suwalsky, 2013; Ghassabian i sur., 2016). Autori Leisman, Moustafa i Shafir (2016) proučavali su motoričke i kognitivne vještine u kontekstu dvonožnosti kod ljudi kao kanala za evoluciju moždane kore. Piaget je smatrao da su kognitivni i motorički razvoj djece usko povezani i bio je prvi koji je istraživao kako se inteligencija razvija iz kontakta s vanjskim svijetom (Wadsworth, 1996).

Prema izvješću CDC-a (Centers for Disease Control) iz 2013. godine, u Sjedinjenim Američkim Državama jedno od 6 djece razvije neki od neurorazvojnih poremećaja u ranoj dječjoj dobi (Boyle i sur., 2011). U posljednjem desetljeću bilježi se porast neurorazvojnih poremećaja od 17\% (Yeargin-Allsopp i 
Jandroković, I., Stošić, J., Spontano generirani pokreti kao prediktori neurorazvojnih poremećaja, Klinička psihologija 13 (2020), 1-2, 107-120

sur., 2011). Zahvaljujući napretku u području neonatalne skrbi značajno je smanjen perinatalni morbiditet, no broj visokorizične novorođenčadi sve je veći. Unatoč tome, nastojanja da se u najranijoj dobi predvidi neurorazvojni ishod su ograničena. Dio problema leži u obilježjima stalno razvijajućeg živčanog sustava. Stalne razvojne promjene u mozgu tijekom perinatalnog razdoblja i novorođenačke dobi te ranog djetinjstva mogu voditi do toga da se izgube znakovi disfunkcije koji su bili prisutni u prvom periodu razvoja. Kroz neprestano sazrijevanje otkriva se i izražava neka disfunkcija koja do tada nije bila izražena (Touwen, 1976; Hadders-Algra, 1996; Roth i sur., 1994). Nadalje, tijekom ranog razvoja dešavaju se kontinuirane promjene u strukturi i funkciji mladog neurološkog sustava te to zahtijeva definiciju po dobi specifičnih kriterija za patologiju (Prechtl, 1977; Dubowitz i Dubowitz,1981).

Tijekom prošlog stoljeća došlo se do mnogih spoznaja o mehanizmima koji upravljaju razvojem funkcija središnjeg živčanog sustava. Na području motoričke kontrole, spoznaje u okviru razvojne neurofizologije dovele su do promjene s koncepta kako su motorička ponašanja naširoko kontrolirana refleksnim mehanizmima (Sherrington, 1906., Magnus i DeKleijn, 1912) na spoznaju kako je motorika krajnji rezultat aktivnosti kompleksnih spinalnih mehanizama koji se nazivaju središnji generatori obrazaca (SGO), engl. Central Pattern Generators (CPGs ) (Gillner i sur., 1995). Također je dokazano kako središnji živčani sustav nije pasivan organ, iz čega proizlazi pretpostavka kako su mehanizmi pokretanja, disanja, gutanja i žvakanja bazirani na središnjim generatorima obrazaca (SGO) (HaddersAlgra, 2007). SGO su neuralne mreže koje imaju sposobnost da uz minimalni senzorički ulaz ili minimalne razine neuroaktivnih tvari kao što su serotonin ili ekscitatorna aminokiselina, koordiniraju aktivnost mnogih mišića (Cazalets, Squalli-Houssaini i Clarac, 1992).
Posljedica središnjih generatora obrazaca su spontane aktivnosti u SŽS-u koje se sastoje od ritmičnog stvaranja akcijskog potencijala koji je povezan s preko desetak stotina stanica i pojavljuje se periodično u razmacima od jedne minute (Feller, 1999). Pretpostavlja se kako je ta periodičnost rezultat aktivnosti mreža $s$ visokom međupovezanosti pobuđujućih sinapsi (O’ Donovan, 1999; Hanson i Landmesser, 2003). Spontana aktivnost SŽS-a ima niz različitih funkcionalnih posljedica kao što su spontana motorička aktivnost te uspostavljanje i održavanje kortikalnih mreža tijekom razvojnih faza, onda kada senzorni ulaz još ne može biti pravilno obrađen (Penn i Shatz, 1999; Khazipov i Luhmann, 2006). Spontana motorička aktivnost je karakteristika razvoja neuralnih mreža, a ne rezultat postupno razvijajućih unaprijed određenih uzoraka neurološkog sustava ili rezultat povećanja kortikalne kontrole nad takozvanim nižim refleksima (Peiper, 1963). To dovodi do zaključka kako bi opservacija spontanog motoričkog ponašanja ili spontano generiranih pokreta (SGP) mogla doprinijeti procjeni neurološkog statusa kod novorođenčadi (Prechtl, 2001; Hadders-Algra, 2004).

\section{Spontano generirani pokreti}

Spontano generirani pokreti (SGP) prvi su pokreti koje ljudski fetus razvija. Pojavljuju se prije izoliranih pokreta udova, a mogu se zapaziti vrlo rano u prenatalnom periodu ( $\mathrm{Za}$ putović, Stanojević i Mišković, 2010). Prisutni su od 7. tjedna trudnoće do 16. tjedna postterminske dobi (Einspieler i Prechtl, 2005). Dosadašnji klinički značaj, ne samo zbog bolje izvedivosti procjene, pokazali su oni spontano generirani pokreti koji se pojavljuju i koji su opažani postnatalno. Kvalitativna podjela tih pokreta dijeli ih u dvije skupine. To su pokreti uvijanja (engl. writhing age), koji su 
prisutni od 0. do 6. tjedna posterminske dobi (Prechtl i Hopkins, 1986). Po svojoj kvaliteti, to su brzi pokreti koji uključuju cijelo tijelo i izgledaju kao uvijanje tijela i udova. Njihovo primarno obilježje je neodređen slijed pokreta ruku, nogu, vrata i trupa. Uglavnom, ovi su pokreti eliptičnog oblika, što je komponenta pokreta koja nam ostavlja dojam uvijajućeg karaktera (Einspieler, Prechtl, Ferrari, Cioni i Bos, 1997). Druga kategorija pokreta su pokreti vrpoljenja. Pojavljuju se u dobi od 8 . do 20. tjedna postterminske dobi. Kvalitativno ti su pokreti male amplitude i umjerene brzine. Ruke se glatko izmjenjuju u fleksiji i ekstenziji, zglobovi se rotiraju, a prsti kreću s finoćom (Prechtl i Hopkins, 1986).

\section{Neurobiološka osnova spontano generiranih pokreta}

Pojava u varijabilnosti i kompleksnosti SGP-a između 9. i 10. tjedna postmenstrualne dobi, preklapa se s pojavom sinaptičkih mjehurića, što upućuje na sinaptičku aktivnost u takozvanoj kortikalnoj subplate zoni (Molliver, Kostović i Van Der Loos, 1973, Super, Soriano i Uylings, 1998). Privremene veze u subplate zoni formiraju funkcionalno aktivne krugove, koji, kako se pretpostavlja, imaju važnu ulogu kod fetalnog ponašanja kao što su spontano generirani pokreti (Allendoerfer i Shatz, 1994). Nadalje, subplate zona prisutna je i u trenucima najveće aktivnosti tzv. procvata SGP-a tj. između 24. i 36. tjedna postmenstrualne dobi (Kostović i Rakić, 1990; Kostović i Judaš, 2006). Postupan nestanak subplate zone između 36. tjedna postmenstrualne dobi i 3.-6. mjeseca postnatalnog razdoblja preklapa se sa završnom fazom razvoja SGP-a (Krmpotić-Nemanić, Kostović, Bogdanović, Fučić i Judaš, 1988; Hadders-Algra, Bouwstra, Van Goor, Dijck-Brouwer, Muskiet, 2007). Pret- postavlja se kako kortikalna subplate zona ima ključnu ulogu u velikoj neurorazvojnoj transformaciji u dobi od 3 mjeseca postanatalno. Pojava voljnih i cilju usmjerenih pokreta poklapa se s postepenim nestankom kortikalne subplate zone između 36. tjedna postmenstrualne dobi i 3.-6. mjeseca postnatalno. Vođen navedenim spoznajama, Prechtl (1990) je otkrio kako bi kvaliteta spontanih pokreta fetusa i novorođenčeta (SGP) mogla biti pokazatelj sazrijevanja, integriteta i funkcioniranja mladog SŽS-a. Ključne riječi u opisu kvalitete SGP-a su varijabilnost i složenost. Neprestane varijacije u procesima fleksije-ekstenzije, abdukcije-adukcije i rotacije odraz su varijacije pokreta, što govori u prilog teoriji kako je varijabilnost pokreta fundamentalna karakteristika funkcioniranja zdravog živčanog sustava u novorođenčadi, a stereotipija oznaka rane neuralne disfunkcije (Touwen, 1978). Navedene spoznaje dovele su do razvoja metode rane procjene novorođenčadi temeljene na evaluaciji kvalitete SGP-a (Ferrari, Cioni i Prechtl, 1990; Prechtl, 1990).

\section{Procjena spontano generiranih pokreta}

Procjena SGP-a prema Prechtl metodi procjene (1990) neinvazivna je i ne zahtijeva skupocjenu opremu te je kratkog vremenskog trajanja (Hadders-Algra i Grothius, 1999). U samoj procjeni spontano generiranih pokreta moguće je razlikovati četiri skupine pokreta: dvije vezane uz tipične SGP (tipično-optimalni, tipično-suboptimalni) i dva oblika atipičnih, tzv. patoloških SGP (blago i jasno atipični SGP) (Hadders-Algra, 2018). Tipično-optimalni SGP pojavljuju se samo u 1020\% novorođenčadi od 3 mjeseca rođenih u terminu, dok većina novorođenčadi pokazuje tipično-suboptimalne pokrete (Hadders-Al- 
Jandroković, I., Stošić, J., Spontano generirani pokreti kao prediktori neurorazvojnih poremećaja, Klinička psihologija 13 (2020), 1-2, 107-120

gra, 2007). Blago atipični pokreti imaju nedovoljan varijabilitet i kompleksnost te nisu fluentni, dok su definitivno jasno atipični SGP vidljivi bez ikakve kompleksnosti, varijabiliteta i fluentnosti (Hadders-Algra, 2007). Prisutnost grčevito-sinkroniziranih pokreta smatra se patološkim te upućuje na značajan gubitak supraspinalnog utjecaja (Hadders-Algra, 1996). Sva novorođenčad s tipično-optimalnim spontanim pokretima ima uredan neurorazvojni ishod. S druge strane, 70\% ili više novorođenčadi s trajno jasno atipičnim spontanim pokretima imaju kasnija neurorazvojna odstupanja uključujući i cerebralnu paralizu, a ishod djece s blago atipičnim SGP je malo poznat i istraživan (Hadders-Algra i sur., 2004). Različiti prenatalni, perinatalni i neonatalni nepovoljni čimbenici kao što su intrauterino zaostajanje u rastu (IUGR), prematuritet, perinatalna asfiksija, neonatalna hiperbilirubinemija, izlaganje ploda antiepilepticima i slično mogu dovesti do atipičnih SGP-a (HaddersAlgra, 2001; Soorani-Lunsing, Woltil i Hadders-Algra, 2001; Parisi i sur. 2003).

Najvažniju ulogu u procjeni imaju takozvani pokreti vrpoljenja. Oni su dio repertoara spontane motorike koji se pojavljuje između 3. i 4. mjeseca života, a završava pojavom antigravitacijskog položaja i voljne motorike. Neuromorfološki nestanak pokreta vrpoljenja poklapa se s nestankom subplate zone $\mathrm{u}$ razvoju kore velikog mozga. Dosadašnje studije veću su važnost pridale upravo prediktivnosti pokreta vrpoljenja u odnosu na pokrete uvijanja koji su prisutni u prvih 1-2 mjeseca do kraja prvog mjeseca života (Prechtl, 1990; Hadders-Algra i Grothius, 1999). Čak i onda kada ultrazvuk mozga pokaže odstupanje ili anamneza upućuje na rizik od kasnijeg neurološkog deficita, prisutnost pokreta vrpoljenja koji su po kvaliteti tipični imaju veću prediktivnost za tipičan razvoj. Suprotno tome, gotovo sva novorođenčad kod koje su pokreti vrpoljenja odsutni imaju veliki rizik za neuro- loške deficite kao što je cerebralna paraliza ili za genetske poremećaje s kasnijom pojavom kliničke slike. Ako pokreti vrpoljenja postoje, ali posturalne reakcije nisu u skladu s dobi te su pokreti po kvaliteti monotoni, kognitivne i jezične funkcije u kasnijoj dobi uglavnom su obilježene manjim ili većim odstupanjima (Salavati i sur., 2017). Povezanost između atipičnosti bijele tvari vidljive na magnetskoj rezonanci (MRI) i odsutnosti pokreta vrpoljenja kod novorođenčadi rođene prije 30. tjedna gestacije podupire činjenicu kako atipični SGP odražavaju oštećenje bijele tvari (Spittle i sur., 2007).

Do danas se procjena SGP-a ustalila kao standard za predviđanje motoričkog razvoja, tj. mogućnosti za razvoj cerebralne paralize u skupini neurorizične dojenčadi. Iako kao standard u procjeni rizika razvoja u Hrvatskoj još nije zaživjela, u svijetu se kao prediktor za razvoj cerebralne paralize koristi već 20 godina. Međutim, ne koristi se kao prediktor za odstupanja u drugim područjima razvoja kao što su opći kognitivni razvoj, jezično-govorni razvoj, komunikacijski razvoj, adaptivne vještine, socijalizacija i slično. Razlog tome leži u činjenici kako se procjena SGP-a uglavnom radi samo kod neurorizične dojenčadi, te kod one koja već u prvim danima po rođenju pokazuje značajna odstupanja. Ono što je nepoznato jest što se događa sa svom drugom novorođenčadi kod koje nakon samog rođenja, a prilikom prve procjene neurološkog statusa nisu vidljiva značajna odstupanja, ali ipak u kasnijoj dobi razviju neki od poremećaja iz područja komunikacije, spoznaje, socijalizacije, jezika i govora. Kao što je navedeno, dosadašnja istraživanja su pokazala da su SGP odraz funkcioniranja i sazrijevanja mladog središnjeg živčanog sustava te se postavlja pitanje je li moguće procjenom SGP-a već u prva četiri mjeseca postnatalno učiniti probir one novorođenčadi kod koje bi patologija SGP-a mogla biti prediktor kasnijih odstupanja u područji- 
ma razvoja jezika i govora, spoznaje, socijalizacije, komunikacije i adaptivnim ponašanjima. Naime, prva odstupanja u područjima razvoja koja nisu vezana uz isključivo motorički razvoj postaju zamjetna tek u kasnijoj dobi, najranije iza 18 mjeseci postantalno. Velika prednost rane procjene djece te njena visoka prediktivna vrijednost omogućuju pravovremeno uključivanje djece kod koje postoje prvi pokazatelji odstupanja u najprikladnije programe rane stimulacije i intervencije ovisno o najizvjesnijoj dijagnozi. Na taj se način na najbolji način iskorištava vrijeme najjače neuroplastičnosti SŽS-a s ciljem što boljeg neurorazvojnog ishoda za svako dijete. Kako bi uopće mogli krenuti s programima rane intervencije, potrebno je pronaći instrument probira s visokom prediktivnom vrijednošću, ne samo za nastajanje CP-a, već onaj koji bi u najranijoj mogućoj dobi mogao uputiti na odstupanja koja će u kasnijem periodu razvoja kod djece rezultirati nastankom neurorazvojnih poremećaja kao što su, na primjer, poremećaj iz spektra autizma (PSA), komunikacijski poremećaji, specifične teškoće učenja itd.

\section{Povezanost spontano generiranih pokreta $\mathrm{i}$ neurorazvojnih poremećaja}

Novije retrospektivne studije pokazuju kako postoji korelacija u patologiji SGP-a kod one novorođenčadi koja u kasnijoj dobi ima razvojna odstupanja. Malobrojne studije koje postoje pokazale su kako postoji izrazita povezanost između pojave abnormalnih pokreta i dijagnosticiranja neuroloških disfunkcija u kasnijoj predškolskoj i školskoj dobi. Jedna od njih je i studija autora Hitzert, Roze, Braeckel i Bos (2014). U studiji je sudjelovalo 74 ispitanika. Prva točka mjerenja bila je s 3 mjeseca života i procjena se sastojala od procjene snimaka SGP-a tipične novorođenčadi. Folow up procjena kognitivnog, motoričkog razvoja i adaptivnog ponašanja napravljena je u prosječnoj dobi od 5 godina i 11 mjeseci. Procjena je bila sveobuhvatna i sastojala se od procjene inteligencije, pažnje, verbalne memorije, vizuo-prostorne percepcije, vizuo-motorne integracije te procjene motoričkih vještina i ponašanja. Studija je pokazala kako je spontana motorika kod zdrave novorođenčadi u dobi od 3 mjeseca povezana s kasnijim kognitivnim i bihevioralnim, ali ne i motoričkim ishodima u ranoj školskoj dobi. Objašnjenje za to moglo bi se pronaći u činjenici kako je motorički razvoj sve do kraja 4. mjeseca kontroliran, tj. posljedica je sazrijevanja mozga i kao takav dio je spontane motorike, dok nakon 4. mjeseca pokreti kod novorođenčeta počinju biti usmjereni k cilju te su kao takvi dio voljne motorike. Takvi pokreti proizvedeni su sa specifičnom namjerom i motivirani vanjskim podražajem te vrlo vjerojatno uključuju drugačije mehanizme nastanka od onih spontanih. Djeca kod koje je u ranoj dojenačkoj dobi uočen smanjeni repertoar pokreta u školskoj dobi imala su više problema s ponašanjem. To nas vodi do moguće pretpostavke kako smanjeni repertoar spontanih pokreta može odražavati odgođeni ili atipični razvoj onih dijelova mozga koji su uključeni u regulaciju ponašanja u kasnijoj dječjoj dobi. Naime, tijekom drugog i trećeg mjeseca života djeteta značajno se povećava aktivnost kortikalnih područja jednako kao i ona unutar korteksa malog mozga i bazalnih ganglija, odnosno u područjima koja uključuju umrežavanje motoričkih, kognitivnih i bihevioralnih funkcija. Druga pretpostavka je kako monotoni SGP mogu biti odraz ograničene mogućnosti za razvoj manjeg broja strategija motoričkog ponašanja u interakciji s okolinom. Time se naglašava važnost ranog motoričkog ponašanja za razvoj adaptivnih vještina u ranoj školskoj dobi (Bornstein i sur., 2013). Takva opažanja idu u prilog teoriji kako se ra- 
Jandroković, I., Stošić, J., Spontano generirani pokreti kao prediktori neurorazvojnih poremećaja, Klinička psihologija 13 (2020), 1-2, 107-120

đamo s ograničenim setom mreža i veza odgovornih za motoričko ponašanje, čime se umanjuje važnost okoline u učenju motoričkog ponašanja. Nadalje, kao što je već navedeno u uvodu, postavlja se pitanje kada govorimo o utvrđenoj povezanosti između motoričkog razvoja i ostalih domena razvoja, jesu li ona zaista samo bihevioralna posljedica? Odnosno, je li motoričko ponašanje bitno za druge domene razvoja samo u dijelu u kojemu nam motorička aktivnost omogućava učenje i iskustvo ili su moguće neuralni mehanizmi motoričkog razvoja isprepleteni na neuralnoj osnovi s onima koji određuju i kognitivni i jezični razvoj $\mathrm{u}$ djece. Slijedom toga, cilj studije Spittlea i sur. (2010) bio je istražiti biometričke karakteristike mozga (linearna mjerenja mozga na MRI reprezentativnom trodimenzionalnom volumenu mozga), kao prediktora atipičnih SGP-a u dobi od 1 i 3 mjeseca, korigirane u nedonoščadi. Pretpostavljeno je da će atipični SGP biti povezani sa smanjenim metričkim vrijednostima mozga u primarnim motornim područjima, malom mozgu i parietalnom režnju. Osamdeset tri nedonoščadi (gestacijska dob $<30$ tjedana) procijenjeno je u korigiranoj kronološkoj dobi. MRI je korištena u procjeni količine bijele tvari u velikom mozgu te metričke karakteristike velikog mozga $\mathrm{u}$ šest unaprijed definiranih regija mozga (tj. bifrontalna, biparietalna, bočna klijetka i transvenzalni promjer mozga te udaljenost između hemisfera). Procjena SGP-a bila je u dobi od 1 i 3 mjeseca života, prema Prechtlovoj metodi procjene. Rezultati studije pokazali su kako je $63 \%(n=52)$ dojenčadi u 1 . mjesecu života imalo atipične SGP s tim da nije bilo povezanosti između metričkih karakteristika mjerenih dijelova mozga i atipičnih SGP. U dobi od 3 mjeseca 23\% ( $n=18)$ novorođenčadi imalo je abnormalne SGP (odsutni pokreti vrpoljenja $\mathrm{n}=18$; abnormalni pokreti vrpoljenja $\mathrm{n}$ $=0$ ). Rezultati su pokazali kako je smanjeni promjer malog mozga u ekvivalentnoj dobi povezan $\mathrm{s}$ atipičnim SGP $\mathrm{u}$ djeteta $\mathrm{u}$ dobi od 3 mjeseca, neovisno o tome postoje li patologija ili odstupanja u količini i razvoju bijele tvari te postoji li intraventrikularno krvarenje. Uzimajući u obzir činjenicu kako je velik dio razvojnih odstupanja koja ne uključuju motoričke i sindromske poremećaje neupadljiv i neprimjetan do rane predškolske dobi, jasna je problematika i same funkcije takozvane rane intervencije koja krene najčešće tek nakon treće godine života, kada su ključni periodi za razvoj pojedine vještine propušteni.

\section{Povezanost spontano generiranih pokreta $\mathrm{i}$ poremećaja iz spektra autizma}

Također je dostupno nekoliko retrospektivnih studija koje su pokazale da postoji korelacija između blago atipičnih pokreta u novorođenčeta s kasnijim nastankom poremećaja iz spektra autizma.

Poremećaj iz spektra autizma cjeloživotni je poremećaj koji istovremeno zahvaća veći broj razvojnih područja te na različit način utječe na svako od njih, što dovodi do velike raznolikosti razvojnih profila i ishoda (Cepanec, Šimleša i Stošić, 2015). Primarno se odražava teškoćama u socijalnoj komunikaciji, između ostalog i izostankom govora ili atipičnim jezično-govornim razvojem i pristunošću ograničenih, repetitivnih obrazaca ponašanja, interesa i aktivnosti. Taj poremećaj dijagnosticira se najranije u dobi od 2 godine, a često i kasnije. Istraživanja su pokazala da je prosječna dob za postavljanje dijagnoze poremećaja iz spektra autizma nekad i 5 godina (Crane, Chester, Goddard, Henry i Hill, 2016). To znači da postoji razlika od gotovo četiri godine između prosječne dobi pojavljivanja pokazatelja sumnje za dječji razvoj i prosječne dobi postavljanja dijagnoze djetetu s PSA. S obzirom 
na to kako se očekivani period pojave govora događa tek nakon druge godine, a nerijetko se tolerira i do treće, cijeli period za iskorištavanja plasticiteta mozga u ranoj intervenciji je izgubljen. Brojna istraživanja u okviru kojih su se nastojali utvrditi biološki markeri za PSA još uvijek nisu dala rezultate, stoga i dalje upotrebljavamo bihevioralne markere, odnosno procjenu djetetova ponašanja za utvrđivanje PSA-a kod male djece. Činjenica da se dojenčad s PSA-om često opisuje kao hipoaktivna ili previše mirna, ide u prilog teoriji i važnosti ranog motoričkog razvoja kod djece s PSA-om. Različite studije su pokazale kako se kod djece s PSA-om uočavaju motorička odstupanja (Wilson, McCracken, Rinehart i Jeste 2018). Međutim, još uvijek nije poznato imaju li uočena odstupanja u razvoju motorike i kretanja kod djece s PSA-om centralnu ulogu u samoj etiologiji nastanka PSA-a. Rastući broj istraživanja opisuje i pokazuje kako u novorođenčadi koja kasnije razvija PSA postoje specifična obilježja u razvoju motorike i motoričkog ponašanja. Ako postoje poremećaji motorike, oni su u dojenačkoj dobi najizraženiji jer još nisu zamaskirani kompenzacijskim mehanizmima koje dijete razvije sazrijevajući. Moguće je da su motorička ponašanja varijabilna ovisno o regiji mozga u kojem je nastalo oštećenje. Teitelbaum, Teitelbaum, Nye, Freiman i Maurer (1998) su pokazali kako atipični uzorak pokreta kod djece s PSA-om može biti detektiran već rano tijekom dojenačkog doba, pretpostavljajući time kako PSA može biti otkriven već jako rano, neovisno o očekivanom periodu pojave govora ili drugih komunikacijskih ponašanja.

Phagava i sur. (2008) su proveli retrospektivnu studiju analizirajući videosnimke 20 novorođenčadi (17 muških, 3 ženskih) kasnije dijagnosticiranih s PSA-om i 20 djece tipičnog razvoja. Troje novorođenčadi snimljeno je s 8 tjedana postnatalno, 13 tijekom perioda pojave pokreta vrpoljenja između 9. i 21. tjedna postnatalno i 4 novorođenčadi tijekom obje vremenske točke. Rezultati su pokazali kako je 70\% novorođenčadi kod koje je kasnije dijagnosticiran PSA imalo patološke pokrete uvijanja, dok je kod tipične novorođenčadi njih $12,5 \%$ imalo atipične pokrete uvijanja. U periodu pojave pokreta vrpoljenja kod 20,8\% novorođenčadi uočena je odsutnost pokreta vrpoljenja, a njih 29,2\% imalo je atipične pokrete vrpoljenja. Dok je u kontrolnoj skupini $88,9 \%$ novorođenčadi imalo tipične pokrete vrpoljenja, a u svega $11,1 \%$ novorođenčadi ti pokreti su bili odsutni. Rezultati studije time su pokazali kako se već u ranoj dobi kod djece kasnije dijagnosticirane s PSA-om uočava odstupanje u ranom spontanom motoričkom ponašanju i to već tijekom prva dva mjeseca života.

\section{ZAKLJUČAK}

Iako su istraživanja SGP-a prisutna već najmanje zadnjih 30 godina u svijetu dječje razvojne neurologije i neurofiziologije, većina ih je bazirana na istraživanjima vezanima uz visoki neurorizik te posljedično nastanak cerebralne paralize i drugih težih motoričkih odstupanja. Ipak kroz istraživanja same neurofiziologije nastanka SGP-a i novim spoznajama o neurobiologiji kognitivnog razvoja kod male djece došlo se do zanimljivih spoznaja kako motorički razvoj i kognitivni razvoj nisu paralelni procesi, već potencijalno slijede iste obrasce i mehanizme nastanka. Sve je veći broj istraživanja koji jasno potvrđuju i učvršćuju simbiozu između motoričkog i kognitivnog razvoja te navode na promišljanje kako bi potencijalno uočavanje ranih motoričkih odstupanja moglo voditi $\mathrm{k}$ prepoznavanju i ranih kognitivnih odstupanja te onih vezanih uz ostale domene razvoja. Pri tom nije važno samo rano prepoznati potencijalno odstupanje te time predvidjeti razvojni ishod pojedi- 
nog djeteta. Rana dijagnostika sama po sebi nema smisla ako nemamo mogućnost i za intervenciju. Kod djece s odstupanjima koja nisu primarno motorička, isključujući i sindromske poremećaje, učestalo se i sama dijagnostika provodi tek u kasnijoj dobi, a najranije oko treće godine života. Također, u neke djece s poremećajem iz spektra autizma koja nemaju jako očite teškoće u ranoj dobi, dijagnoza se postavlja tek u školskoj dobi.

Time se propuštaju takozvani "prozori za mogućnost učenja”. To je pojam koji se koristi kako bismo opisali najpovoljnije vremensko razdoblje za učenje i usvajanja određene vještine ako za nju postoje preduvjeti (Hensch i Bilimoria, 2012). Događa se izrazitom brzinom te kada prođe taj period, iako i dalje zbog neuroplastičnosti postoji mogućnost učenja i usavršavanja razvoja te vještine, ona će se teško ikada u potpunosti razviti. Vođeni time, lako možemo uvidjeti važnost rane intervencije za dječji razvoj. Iz tog razloga, rani probir za neurorazvojne poremećaje je nešto čemu se teži u ranom periodu dječjeg razvoja. Ipak, malo je metoda i tehnika kojima možemo predvidjeti mogućnost za razvojni ishod male djece u kasnijoj dobi. Dosadašnja istraživanja su pokazala kako rana procjena spontano generiranih pokreta može biti prediktivna za kasnije ishode razvoja, a spoznaje iz razvojne neurofiziologije koja uvjetuje i upravlja SGP-om, mogle bi poslužiti za postavljanje teorija o etiologiji neurorazvojnih poremećaja. Primarni cilj bi ipak bio usmjeren na pravu ranu intervenciju već tijekom prve godine djetetova života kod one novorođenčadi koja bi pokazivala odstupanja u razvoju SGP-a. Na taj način bi se, osim razvojne neuroplastičnosti koja je najizraženija tijekom prve dvije godine, iskoristili i "prozori za mogućnost učenja”, tj. poticanje upravo onih vještina iz područja u kojima pretpostavljamo da postoji neka rana predispozicija za razvoj teškoće.

\section{LITERATURA}

Allendoerfer, K. L. i Shatz, C. J. (1994). The subplate, a transient neocortical structure: its role in the development of connections between thalamus and cortex. Annual Review of Neuroscience, 17, 185-218.

Bornstein, M. H., Hahn, C. S. i Suwalsky, J. T. D. (2013). Physically Developed and Exploratory Young Infants Contribute to Their Own LongTerm Academic Achievement. Psychology Science, 24(10), 1906-1917.

Boyle, C. A., Boulet, S., Schieve, L., Cohen. R. A., Blumberg, S. J., Yeargin-Allsopp, M., Visser, S. i Kogan, M. D. (2011). Trends in the Prevalence of Developmental Disabilities in US Children, 1997-2008. Pediatrics, 27, 1034-1042.

Cazalets, J. R., Squalli-Houssaini, Y. i Clarac, F. (1992). Activation of the central pattern generators for locomotion by serotonin and excitatory amino acids in neonatal rat. Journal of Physiology, 455, 187-204.

Cepanec, M., Šimleša, S. i Stošić, J. (2015). Rana dijagnostika poremećaja iz autističnog spektrateorija istraživanja i praksa. Klinička psihologija, 8(2), 203-224.

Crane, L., Chester, J. W., Goddard, L., Henry, L. A. i Hill, E. (2015). Experiences of autism diagnosis: A survey of over 1000 parents in United Kingdom. SAGE Journals, 20(2), 153-162. DOI: $10.1177 / 1362361315573636$.

Diamond, A. (2000). Close Interrelation of Motor Development and Cognitive Development and of the Cerebellum and Prefrontal Cortex. Child Development, 71(1), 44-56.

Dubowitz, L. M. S. i Dubowitz V. (1981). The neurological assessment of the preterm and fullterm newborn infant. Clinics in Developmental Medicine. Blackwell: London.

Einspieler C., Prechtl H. F., Ferrari F., Cioni G., Bos A. F. (1997). The qualitative assessment of general movements in preterm, term and young infants--review of the methodology. Early Human Development, 50(1), 47-60.

Einspieler, C. i Prechtl, H. F. R. (2005). Prechtl's assessment of general movements: A diagnostic tool for the functional assessment of the young nervous system. Mental Retardation and Developmental Disabilities Research Reviews, 11, 61-67. DOI:10.1002/mrdd.20051. 
Feller, M. B. (1999). Spontaneous correlated activity in developing neural circuits. Neuron, 22, 653-656.

Ferrari, F., Cioni, G. i Prechtl, H. F. (1990). Qualitative changes of general movements in preterm infants with brain lesions. Early Human Development, 23(3), 193-231. https://doi. org/10.1016/0378-3782(90)90013-9

Ghassabian, A., Sundaram, R., Bell, E., Bello, S.C., Kus, C. i Yeung, E. (2016). Gross Motor Milestones and Subsequent Development. Pediatrics, 138(1), 1-8. DOI: 10.1542/peds.20154372.

Gillner, S., Deliagina, T., Ekeberg, O., El Manira, A., Hill, R. H., Lansner, A., Orlovsky, G. N. i Wallen, P. (1995). Neural networks that coordinate locomotion and body orientation in lamprey. Trends in Neurosciences, 18, 270-279.

Hadders-Algra, M. (1996). Assessment of General Movements: a valuable technique for detecting brain dysfunction in young infants. Acta Pediatrica, 416, 39-43.

Hadders-Algra, M. (2001). Evaluation of motor function in young infants by means of the assessment of general movements: a review. Pediatric Physical Therapy, 13(1), 27-36.

Hadders-Algra, M. (2004). General movements: a window for early identification of children at high risk of developmental disorders. Journal of Pediatrics, 145, 12-18.

Hadders-Algra, M. (2007). Putative neural substrate of normal and abnormal general movements. Neuroscience and Biobehavioral Reviews, 31(8), 1181-1190.

Hadders-Algra, M. (2018). Neural substrate and clinical significance of general movements: an update. Developmental medicine and child neurology, 60(1), 39-46.

Hadders-Algra, M. i Groothuis, A. M. C. (1999). Quality of general movements in infancy is related to neurological dysfunction, ADHD, and aggressive behaviour. Developmental Medicine and Child Neurology, 41, 381-391.

Hadders-Algra, M., Bouwstra, H., Van Goor, S. A., Dijck-Brouwer, D. A. J. i Muskiet, F. A. J. (2007). Prenatal fatty and early postnatal fatty acid status and neurodevelopmental outcome. Journal of Perinatal Medicine, 35(1), 28-34.

Hadders-Algra, M., Mavinkurve-Groothuis, A. M. C., Groen, S. E., Stremmelaar, E. F., Martijn,
A. i Butcher, P. R (2004). Quality of general movements and the development of minor neurological dysfunction at toddler and school age. Clinical Rehabilitation, 18, 287-299.

Halloway, S., Arfanakis, K., Wilbur J., Schoeny, M. E. i Pressler S. J. (2018). Accelerometer physical activity is associated with greater grey matter volumes in older adults without dementia or mild cognitive impairment. The journals of gerontology. Series B, Psychological sciences and social sciences , 74(7), 1142-1151. DOI: 10.1093/geronb/gby010.

Hanson, M. G. i Landmesser, L. T. (2003). Characterization of the circuits that generate spontaneous episodes of activity in the early embryonic mouse spinal cord. Journal of Neuroscience, 23, 587-600.

Hensch, T. i Bilimoria, P. M. (2012). Re-opening Windows: Manipulating Critical Periods for Brain Development. Cerebrum, 12, 1-18.

Hitzert, M. M., Roze, E., Braeckel, K. N. J. A. i Bos, A. F. (2014). Motor development in 3-monthold healthy term-born infants is associates with cognitive and behavioural outcomes at early school age. Developmental Medicine and Child Neurology, 56, 869-876.

Hofsten, C. (2004). An action perspective on motor development. Trends in Cognitive Sciences, 8(6), 266-272.

Khazipov, R. i Luhmann, H. J (2006). Early patterns of electrical activity in the developing cerebral cortex of humans and rodents. Trends in Neurosciences 29, 414-418.

Kostović, I. i Judaš, M., (2006). Prolonged coexistence of transient and permanent circuitry elements in the developing cerebral cortex of fetuses and preterm infants. Developmental Medicine and Child Neurology, 48, 388-393.

Kostović, I. i Rakić, P. (1990). Developmental history of the transient subplate zone in the visual and somatosensory cortex of the macaque monkey and human brain. Journal of Comparative Neurology, 297, 441-470.

Krmpotić-Nemanić, J., Kostović, I., Bogdanović, N., Fučić, A. i Judaš, M (1988). Cytoarchitectonic parameters of developmental capacity of the human associative auditory cortex during postnatal life. Acta OtoLaryngologica, 195, 463-466.

Leisman, G. i Melillo, R. (2013). The basal ganglia: motor and cognitive relationships in a clinical 
Jandroković, I., Stošić, J., Spontano generirani pokreti kao prediktori neurorazvojnih poremećaja,

Klinička psihologija 13 (2020), 1-2, 107-120

neurobehavioral context. Reviews in the Neurosciences, 24(1), 9-25. DOI: 10.1515/revneuro-2012-0067.

Leisman, G., Moustafa, A. i Shafir, T. (2016). Thinking, walking, talking: Integratory motor and cognitive brain function. Frontiers in Public Health, 94(4), 1-19. DOI: 10.3389/ fpubh.2016.00094.

Magnus, R. i De Kleijn, A. (1912). Die abhängigkeit des Tonus der Extremitätenmuskeln von der Kopfstellung. Pflüger's Archiv, 145, 455-548.

Marrus, N., Eggebrecht, A. T., Elison J. T., Wolff, J. J., Cole, L., Gao, W., Pandey, J., Shen, M. D., Swanson, M. R., Emerson, W. R., Clohr, C. L., Adams, C. M., Estes, A. M., Zwaigenbaum, L., Botteron, K. N., McKinstry, R. C., Constantino, J. N., Evans, A. C., Hazlett, H. C., Dagre, S. R., Paterson, S. J., Schultz, R. T., Steyner, M. A., Gerig, G., The IBIS Network, Schlaggar, B. L., Piven, J. i Pruett, J. R., Jr. (2018). Walking, Gross Motor Development, and Brain Functional Connectivity in Infants and Toddlers. $\mathrm{Ce}$ rebral Cortex, 28(2), 750-763. DOI: 10.1093/ cercor/bhx313

Molliver, M. E., Kostovic, I. i Van der Loos, H. (1973). Development of synapses in cerebral cortex of the human foetus. Brain Research, 50, 403-407.

Murray, G. K., Veijola, J., Moilanen, K., Miettunen, J., Glahn, D. C., Cannon, T. D., Jones, P. B., Isohanni, M. (2006). Infant motor development is associated with adult cognitive categorisation in a longitudinal birth cohort study. Journal of Child Psychology and Psychiatry and Allied Disciplines, 47(1), 25-29.

Niendam, T. A., Laird, A. R., Ray, K. L., Dean, Y. M., Glahn, D. C. i Carter, C. S. (2012). Metaanalytic evidence for a superordinate cognitive control network subserving diverse executive functions. Cognitive, Affective, \& Behavioral Neuroscience, 12(2), 241-268.

O'Donovan, M. J (1999). The origin of spontaneous activity in developing networks of the vertebrate nervous system. Current Opinion in Neurobiology, 9, 94-104.

Parisi, P., Francia, A., Vanacore, N., Fiore, S., Giallonardo, A. T. i Manfredi, M (2003). Psychomotor development and general movements in offspring of women with epilepsy and anticonvulsant therapy. Early Human Development, 74, 97-108.
Peiper, A. (1963). Cerebral Function in Infancy and Childhood, third ed. Consultants Bureau, New York.

Penn, A. A. i Shatz, C. (1999). Brain waves and brain wiring: the role of endogenous and sensory-driven neural activity in development. $P e$ diatric Research, 45, 447-458.

Phagava, H., Muratori, F., Einspieler, C., Maestro, S., Apicella, F., Guzetta, A., Prechtl, H. F. i Cioni, G. (2008). General movements in infants with autism spectrum disorders. Gorgian Medical News, 156, 100-105.

Prechtl, H. F. R. (1977). The neurological examination of the full term newborn infant. Clinics in Developmental Medicine 63. Blackwell: London.

Prechtl, H. F. R. (1990). Qualitative changes of spontaneous movements in fetus and preterm infant are a marker of neurological dysfunction. Early Human Development, 23, 151-158.

Prechtl, H. F. R. (2001). General movement assessment as a method of developmental neurology: new paradigms and their consequences. Developmental Medicine and Child Neurology, 43, 836-842.

Prechtl, H. F. R., Hopkins B. (1986). Developmental transformations of spontaneous movements in early infancy, Early human development, 14(3-4), 233-238.

Roth, S. C., Bauclin, J., Pezzani-Goldsmith, M., Tounsend, J., Reynolds, E. O. R. i Stewart, A. L. (1994). Relation between neurodevelopmental status of very preterm infants at one and eight years. Developmental Medicine and Child $\mathrm{Ne}$ urology, 36, 1049-1062.

Salavati, S., Einspieler, C., Vagelli, G., Zhang, D., Pansy, J., Burgerhof, J. G. M., Marschik, P. B. i Bos, A. F. (2017). The association between the early motor repertoire and language development in term children born after normal pregnancy. Early Human Development, 111, 3035. DOI: 10.1016/j.earlhumdev.2017.05.006.

Sherrington, C. S (1906). The physiological position and dominance of the brain. U: Sherrington, C. S. (Ed.), The Integrative Action of the Nervous System, 308-353.

Soorani-Lunsing, R .J., Woltil, H. i Hadders-Algra, M. (2001). Are moderate degrees of hyperbilirubinaemia in healthy term neonates really safe for the brain? Pediatric Research, 50, 701705 . 
Spittle, A. J., Brown, N., Doyle, L., Boyd, R., Hunt, R., Bear, M. i Inder, T. (2007). Quality of General Movements is related to white matter pathology in very preterm Infants. Pediatrics, 10, 1542, 2007-1924.

Spittle, A. J., Doyle, L. W., Anderson, P. J., Inder, T. E., Boyd, R. N. i Cheong, J. L. (2010). Reduced cerebellar diameter in very preterm infants with abnormal general movements. Early Human Development, 86(1), 1-5. DOI: 10.1016/j.earlhumdev.2009.11.002

Super, H., Soriano, E. i Uylings, H. B (1998). The functions of the preplate in development and evolution of the neocortex and hippocampus. Brain Research Reviews 27, 40-64.

Teitelbaum, P., Teitelbaum, O., Nye, J., Freiman, J. i Maurer, M. G. (1998). Movement analysis in infancy may be useful for early diagnosis of autism. Proceedings of the National Academy of Sciences of the United States of America, 95(23), 13982-13987.

Touwen, B. C. L. (1976). Neurological development in infancy. Clinics in Developmental Medicine, 58. Blackwell: London
Touwen, B. C. L. (1978). Variability and stereotypy in normal and deviant development. In: Apley, J. (Ed.), Care of the Handicapped Child. Clinics in Developmental Medicine, 67, 99-110.

Wadsworth, B .J. (1996). Piaget theory of cognitive and affective development: Foundations of constructivism 5th edition. USA: Longman Publishing.

Wilson, R. B., McCracken, J. T., Rinehart, N. J. i Jeste S. S. (2018). What's missing in autism spectrum disorder motor assessments? Journal of Neurodevelopmental Disorders. 10(33).

Yeargin-Allsopp, M., Boyle, C. A., Boulet, S., Schieve, L., Cohen, R. A., Blumberg, S. J., Visser, S. i Kogan M. D.(2011). Trends in the Prevalence of Developmental Disabilities in US Children, 1997-2008. Pediatrics, 27, 1034-1042.

Zaputović S., Stanojević M., Mišković B. (2010). Od fetalne do neonatalne neurologije. Gynaecologia et perinatologia: Journal for gynaecology, perinatology, reproductive medicine and ultrasonic diagnostics, 19(1), 16-24.
Korespondencija: Ivana Jandroković

Edukacijsko-rehabilitacijski fakultet Sveučilišta u Zagrebu, Borongajska 83 f, 10000 Zagreb ivana.jandrokovic@erf.unizg.hr
Primljeno: 18. 02. 2020.

Prihvaćeno: 24. 09. 2020.

Online: $\quad 30.10 .2020$

Print: $\quad 27.11 .2020$

\section{Spontaneously generated Movements as Predictors of Neurodevelopmental Disorders}

Abstract: In this paper, previous research on general movements $(\mathrm{GM})$ and their role as predictors of
neurodevelopmental disorders is presented. One of six children shows some degree of neurodevelopmen-
tal disorders in early childhood. Methods for predicting neurodevelopmental outcomes that can be im-
plemented at an early age are limited. General movements (GM) in the neonatal period are indicators of
spontaneous neural activity and of brain damage. The assessment of GM has a high predictive value for the
development of cerebral palsy but the predictive value of $\mathrm{GM}$ assessment for the development of other
nonmotor neurodevelopmental delays is not yet clearly established. The quality of GMs is based on the inte-
grity of the subplate zone and its connections. Many studies have shown that atypical GMs are an indicator 
Jandroković, I., Stošić, J., Spontano generirani pokreti kao prediktori neurorazvojnih poremećaja, Klinička psihologija 13 (2020), 1-2, 107-120

of brain damage or of subplate zone dysfunction and its efferent connections in the periventricular white matter, which, consequently can lead to dysfunction in several abilities that are the result of optimal functioning of complex cortico-subcortical neuronal circuits. Subsequently, assessment of GMs can be predictive for neurodevelopmental disorders and enable timely implementation of early intervention.

Key words: general movements, general movements assessment, neurodevelopmental disorders, autism spectrum disorders 
